\title{
REVIEW
}

\section{ALEXANDER FIDORA AND GÖRGE K. HASSELHOF (EDS.). THE TALMUD IN DISPUTE DURING THE HIGH MIDDLE AGES. BELLATERRA: SERVEI DE PUBLICACIONS DE LA UNIVERSITAT AUTÒNOMA DE BARCELONA, 2019}

\author{
Mario Macías \\ (Institute of Law and Technology, Universitat Autònoma de Barcelona) \\ mario.macias@uab.cat
}

\begin{abstract}
Volume: Alexander Fidora and Görge Hasselhoff (Eds.). The Talmud in Dispute During the High Middle Ages. Col. Documents, vol. 116. Bellaterra: Servei de Publicacions de la Universitat Autònoma de Barcelona, 2019, pp. 282, ISBN-10: 8449089468, ISBN-13 : 978-8449089466.

Acknowledgements: Project IEC PRO2018-S05. Models del dret i la filosofia política catalanes: semàntica de les doctrines juridicopolítiques del pactisme en les seves diferents fases [Models of Catalan political philosophy and law: Semantics of pactmodel driven political and legal doctrines at their different stages].

Disclosure statement: No potential conflict of interest was reported by the authors.

License: This work is under Attribution-NonCommercial-NoDerivs 3.0 Unported (CC BY-NC-ND 3.0) http://creativecommons.org/licenses/by-nc-nd/3.0/

Suggested citation: Macías, M. (2019-2020). "Alexander Fidora and Görge K. Hasselhof (eds.). The Talmudin Dispute During the High Middle Ages. Bellaterra: Servei de Publicacions de la Universitat Autónoma de Barcelona, 2019, 282 p.”, Journal of Catalan Intellectual History 12: pp. 115-117 DOI: 10.2478/jocih- 2019-0009
\end{abstract}

(C)2021, Journal of Catalan Intellectual History

The Talmud in Dispute During the High Middle Ages has been produced in the framework of the ERC project The Latin Talmud and Its Influence on Christian-Jewish Polemic (LATTAL). The aim of this project, which finalized in 2019, was the study of the use of Jewish sources by Christian scholastics as apologetic materials to probe the veracity of the Catholic dogma and the falsities of Judaism. Alexander Fidora, principal researcher of the project and ICREA research professor at the Autonomous University of Barcelona, is also the editor of this exhaustive book composed by ten independent contributions on the Disputation of Paris and the Latin translations of the Talmud in the mid-thirteenth century.

Throughout its lifetime, the LATTAL project has addressed several apologetic works and authors of that period. In this sense, the wide range of publications resulting from the project-like the collective book Ramon Martís Pugio fidei: Studies and Texts (2018), for example- have contributed to enlarge our knowledge on the anti-Jewish missionizing zeal that characterized the Late Middle Ages. 
Nevertheless, the main - and now accomplished - goal of the project has been the study and edition of the Extractiones de Talmud, an anthological Latin translation of 2,000 Talmudic passages terminated ca. 1245. This text was the culmination of a process initiated in 1238, when the convert Franciscan friar Nicholas Donin submitted to Pope Gregory IV the De articulis litterarum Papae, a list of thirty-five accusations against the Jewish faith based on Talmudic materials. These accusations motivated the Disputation of Paris (1240), the first public large-scale theological disputation relying on Jewish sources. This event, and the subsequent burning of the Talmud, soon became a cornerstone in the history of Christian-Jewish relations.

As evinced by all the participating authors, the discovery of the Talmud was culturally groundbreaking for Western Christendom. Donin's accusations were the very first Latin translation of Talmudic passages. Innocent IV, aiming to consummate the process initiated in Paris, entrusted the task of expanding the translations to Cardinal Odo of Châteauroux. His team, which probably had already taken part in the elaboration of the De articulis, produced the Extractiones. This compilation was soon followed by additional materials and translations gathered in the so-called Dossier, whose composition is discussed by Ulisse Cecini and Óscar de la Cruz in their contribution.

The edition of the Extractiones de Talmud, elaborated by Cecini and de la Cruz, became available in 2018. On its part, the Talmud in Disptue can be seen as an exhaustive companion to this edition. The rich overall background of the participating authors contributes to offer a multidisciplinary approach covering all the relevant aspects surrounding the Extractiones. Textual and linguistic analyses, as well as contextualizing historical research, converge in this essential work.

The first noteworthy input of this book is the critical edition of several Latin translations of Talmudic texts and other Jewish sources. Perhaps the most relevant of these works is the edition of the De articulis litterarum Papae prepared by Professor Piero Cappeli. This new version, thanks to the meticulous reconstruction of all the available manuscripts, largely improves the edition published by Isidore Loeb in 1880-1881.

Equal attention must be paid to the appendixes to the chapters by Enric Cortés and Wout van Bekkum. Cortes focuses on the predilection of Christian authors for the Sanhedrin treatise-also addressed by Eulàlia Vernet-, which was believed to contain clarifying elements on the judicial process against Christ. The chapter finishes with the Latin translation of Sanhedrin 96a-97a. On his part, van Bekkum examines the obscure Liber Krúbot, one of the few Latin translations of Hebrew hymns and liturgical poems, and includes an edition of this compilation conducted by Professor Hasselhoff.

Textual and comparative studies - especially the chapters written by Ursula Ragacs, Eulàlia Vernet and Görge Hasselhoff, as well as those by van Bekkum and Cortés-evince the biased character of the Christian approaches to the Talmud. Translations were not motivated by a sincere intellectual interest; their objective was to become apologetic weapons against the enemies of the true faith. They are full of deliberate omissions and misinterpretations highlighting the negative aspects and lies of Judaism. On the other hand, it was commonly believed that Jewish sources, though false and blasphemous, could contain theological evidences on the veracity of the Catholic dogma. These were, in fact, the two rationales behind the study of the Talmud. In ad- 
dition to these manipulations, dal Bo and Cortés point out the difficulties inherent to a crosscultural translation of such a complex legal and theological code.

But beyond linguistic and philological considerations, the greatest achievement of The Talmud in Dispute is its historiographical contribution to the study on the origins of the rising antiJewish hostility, which culminated in dramatic events like the massacres of 1391 in the Iberian Peninsula. The discovery of the Talmud shook the traditional perceptions on Judaism based on the Augustinian theses. If once considered a stagnant and anachronistic people incapable of producing new theological material, the existence of the Talmud evinced their intellectual depth. Thus they were not ignorant, as Augustine alleged, but heretics and blasphemers, a real threat for the Catholic dogma. In his contribution, Federico dal Bo describes the Disputation of Paris and the burning of the Talmud as an emotional reaction to this discovery.

The chapters written by Federico dal Bo, Alexander Fidora and Moises Orfali target the impact of these translations in the aggressive apologetic activity of the Late Middle Ages. Dal Bo deals with the immediate consequences of the breakthrough of the Talmud in West Europe. He also discusses how its complex internal structure and transmission process prevented Christian scholars from penetrating in the richness of the Talmud. Fidora traces the influence of the De articulis and the Extractiones in the polemicliterature of the second half of the thirteenth century and earlier years of the fourteenth century. Finally, Orfali's contribution closes the list of chapters with a study on the influence of these translations in Hieronymus of Sancta Fide and the Disputation of Tortosa (1413-1414).

This book, therefore, sheds light on the enigmatic process that led Christianity to move forward from a tense tolerance towards Judaism to intellectual conflict and then to physical violence. Dozens of bright previous publications have provided deep insights on this conundrum, like the works of Jeremy Cohen and David Nirenberg, among many others. Nevertheless, the rich range of scholarly approaches offered in this book proves that the study of such a social evolution requires wider academic perspectives. There are still many questions claiming for an answer and many research lines that need to be explored, but the Talmud in Dispute - as well as the other outputs of the LATTAL project—might be regarded an important milestone in this historiographic path. 